\title{
Effect of Potassium on the Leaching of Chemical Species in a Soil Treated With Sewage Sludge
}

\author{
Edmilson Cezar Paglia*, Beatriz Monte Serrat, Clarice Azevedo de Luna Freire, Ana Rosa dos \\ Anjos Sirtoli and Andrea Mayer Veiga \\ Setor de Ciências Agrárias; Universidade Federal do Paraná; Rua dos Funcionários, 1540; Juvevê; \\ edpaglia@yahoo.com.br;80000-050; Curitiba - PR - Brasil
}

\begin{abstract}
The objective of this research was to evaluate the potassium interference, used as supplementary fertilization, in the ions leaching, in a soil that was treated with alkalinized sewage sludge and cultivated, with maize. The experimental set with sewage sludge results showed an increase of the potassium concentration and chloride concentration in the leached solution, as well as the reduction of the $A l^{3+}$ concentration, as the doses of potassium fertilizer applied to the soil were increased, for the four leachings. The presence of sewage sludge treated with lime increased the concentration of $\mathrm{NO}^{3-}, \mathrm{Cl}^{-} \mathrm{Ca}^{2+}, \mathrm{Mg}^{2+}$ and $\mathrm{Al}^{3+}$ in the solutions in the majority of leachings. Values of $\mathrm{Al}^{3+}$ were higher than $0.1 \mathrm{mg} \mathrm{L}^{-1}$, than in all leachings when sewage sludge was added to the soil. For nitrate, all the solutions presented values higher than the maximum value allowed by the current law $\left(10 \mathrm{mg} \mathrm{L}^{-1}\right)$.
\end{abstract}

Key words: Biosoli, ionic leaching, water contamination, environmental pollution

\section{INTRODUCTION}

Agriculture is the most promising alternative of sewage sludge recycling, under both, the environment aspect as well as the economic aspect, because it could transform the residues in an important agriculture input. The agricultural use of sewage sludge must, however, be based on careful studies that define agricultural, environment and sanitary criteria, in order to guarantee its safe use (Andreoli, 1999). The treatment of sewage sludge by aerobic methodology, disinfected with lime, favors the loss of potassium and modifies the nutrients balance of the organic composition due to addition of cations as calcium and magnesium, being able to produce, some times, a negative effect over the potassium absorption, and over the soil solution ionic composition. These aspects induced researches that found the occurrence of $\mathrm{K}$ leaching and the $\mathrm{K}$ supplementation requirement to the use in agriculture (Anjos, 1999; Silva, 1995; Oliveira et al., 1995 and Berton, 1989).

However, not much information is available on ions interaction in the soil and their potential to contaminate subsurface layers of soil and underground water clue to the effect of sewage sludge. The objective of this work was to evaluate the potassium interference used as supplementary fertilizer in the leaching of ions in a soil that was treated with sewage sludge alkalinized, as well as the potential of this biosolid to contaminate underground waters by ions.

\footnotetext{
${ }^{*}$ Author for correspondence
} 


\section{MATERIALS AND METHODS}

Experiment was carried out in two experimental phases, first one following Veiga (2002), and second in columns of soil without crop coverage. Two sets of units were installed, first soil added with alkalinized sewage sludge and various potassium doses $(0,50,100,150,200 \%$ of the $\mathrm{K}_{2} \mathrm{O}$ ), and second with soil without alkalinized sewage sludge (ASS) $\left(60 \mathrm{~kg} \mathrm{ha}^{-1}\right.$ of $\left.\mathrm{K}_{2} \mathrm{O}\right)$ with dose of potassium. The soil used was Dystrophic Red Latosol, with medium texture.

The soil received lime application in the layer of $0-20 \mathrm{~cm}$ to achieve $60 \%$ of bases saturation. The original $\mathrm{pH}$ of the soil, in $\mathrm{CaCl}_{2}$, in the superficial layer (0-20 cm of depth), was 4.2 to 5.2 after the lime application. The $\mathrm{pH}$ of the soil with alkalinized sewage was 5.5. The first set (with alkalinized sewage sludge) was treated with 8.98 $\mathrm{Mg} \mathrm{ha}^{-1}$ of alkalinized sewage sludge, in dry bases (pH -12.05; P-8.47 $\mathrm{g} \mathrm{kg}^{-1} ; \mathrm{K}-3.72 \mathrm{~g} \mathrm{~kg}^{-1} ; \mathrm{Ca}-112$ $\mathrm{g} \mathrm{kg}^{-1} ; \mathrm{Mg}-60.5 \mathrm{~g} \mathrm{~kg}^{-1} ; \mathrm{N}-24.85 \mathrm{~g} \mathrm{~kg}^{-1} ; \mathrm{U}-60^{\circ} \mathrm{C}$ $64.6 \%$ ). Veiga (2002) application of ASS was based on its availability of $\mathrm{N}$, its neutralization power and the maximum allowable heavy metal concentrations in the soil (PROSAB, 1999; Fernades and Andreoli, 1997).

The $\mathrm{K}_{2} \mathrm{O}$ rates for this experiment was based on the soil chemical analysis, sampled after corn harvest (Table 1). The criterium was the same as used in the field phase from the Soil Fertility Commission RS/SC (1994), for corn $\left(60 \mathrm{~kg} \mathrm{ha}^{-1}\right)$. The first experimental set received five rates of $\mathrm{K}_{2} \mathrm{O}$ as potassium chloride, the second experimental set received only the integral dosege recommended $\left(60 \mathrm{~kg} \mathrm{ha}^{-1}\right.$ of $\left.\mathrm{K}_{2} \mathrm{O}\right)$.

The experiment was compounded by 22 experimental units, with 15 from the experimental set whit ASS (3 recurrence and 7 from the set without ASS (7 recurrences).

Table 1 - The soil Chemical characteristics after the maize harvesting at the conclusion of the first experimental phase average from the horizon $0-20 \mathrm{~cm}$

\begin{tabular}{|c|c|c|c|c|c|c|c|c|c|c|c|}
\hline & pH & $\mathrm{Al}^{3+}$ & $\mathrm{H}+\mathrm{Al}$ & $\mathrm{Ca}+\mathrm{Mg}$ & $\mathrm{Ca}^{2+}$ & $\mathbf{K}^{+}$ & $\mathbf{T}$ & $\mathbf{P}$ & C & pH & $\mathbf{V}$ \\
\hline & $\left(\mathrm{CaCl}_{2}\right)$ & \multicolumn{6}{|c|}{$\mathrm{cmol}_{\mathrm{c}} \mathrm{dm}^{-3}$} & $\mathrm{mg} \mathrm{dm}^{-3}$ & $\mathrm{~g} \mathrm{dm}^{-3}$ & (SMP) & $(\%)$ \\
\hline $\begin{array}{c}\text { Set without } \\
\text { ASS* }\end{array}$ & 5,10 & 0,00 & 4,63 & 4,18 & 2,81 & 0,07 & 8,88 & 6,9 & 19,46 & 6,10 & 47,66 \\
\hline \multirow{5}{*}{$\begin{array}{l}\text { Set with } \\
\text { ASS** }\end{array}$} & 5,60 & 0,00 & 3,33 & 7,13 & 5,23 & 0,046 & 10,51 & 3,73 & 19,6 & 6,53 & 68,20 \\
\hline & 5,50 & 0,00 & 3,33 & 6,66 & 4,23 & 0,053 & 10,05 & 10,40 & 19,20 & 6,53 & 66,80 \\
\hline & 5,50 & 0,00 & 3,33 & 5,93 & 3,60 & 0,070 & 9,33 & 8,00 & 19,20 & 6,53 & 64,13 \\
\hline & 5,50 & 0,00 & 3,06 & 6,50 & 3,80 & 0,083 & 9,65 & 10,70 & 20,40 & 6,66 & 68,20 \\
\hline & 5,60 & 0,00 & 3,26 & 6,46 & 3,60 & 0,083 & 9,81 & 10,10 & 19,60 & 6,56 & 66,73 \\
\hline
\end{tabular}

In the second phase, the experimental units had been made with PVC columns with $7.5 \mathrm{~cm}$ of diameter and $63 \mathrm{~cm}$ of height Fig. 1, filled with soil and installed in the Agricultural Science Sector greenhouse from Universidade Federal do Paraná (UFPR), in Curitiba, PR. The columns had been filled from the bottom, at each $20 \mathrm{~cm}$, with samples from soil layers of $20-40 \mathrm{~cm}$ and $0-20 \mathrm{~cm}$ of depth, after sifted in mesh of $4 \mathrm{~mm}$. The layers of soil were separated each other with a thin plastic screen, as well as the bottom part of the columns, which had been supported on funnels for leached solution's collection.
The leaching process was carried through based on a region annual precipitation average of $1400 \mathrm{~mm}$ year-1, using a quota of $1 / 12$ of the annual average precipitation, for each one of four leachings, spaced monthly.

The rain simulation was executed by dripping process (500 $\mathrm{ml}$ serum bottles, with equipment) installed in the superior part of the columns, with outflow of $12 \mathrm{ml} \mathrm{min}^{-1}$. The nitrate determination, in the leached solution, was effected by ultraviolet absorption spectrophotometer (Myazawa et al., 1985). The chloride determination was realized calorimetrically (Tedesco et al., 1995); the sulfate 
determination was done turbodimetry (Eaton et al., 1995); the phosphate determination (Murphy and Riley, 1962); the potassium determination was done by atomic emission (Perkin-Elmer, 1973); and the calcium determination, magnesium, and aluminum was carried through by atomic absorption (Perkin-Elmer, 1973).

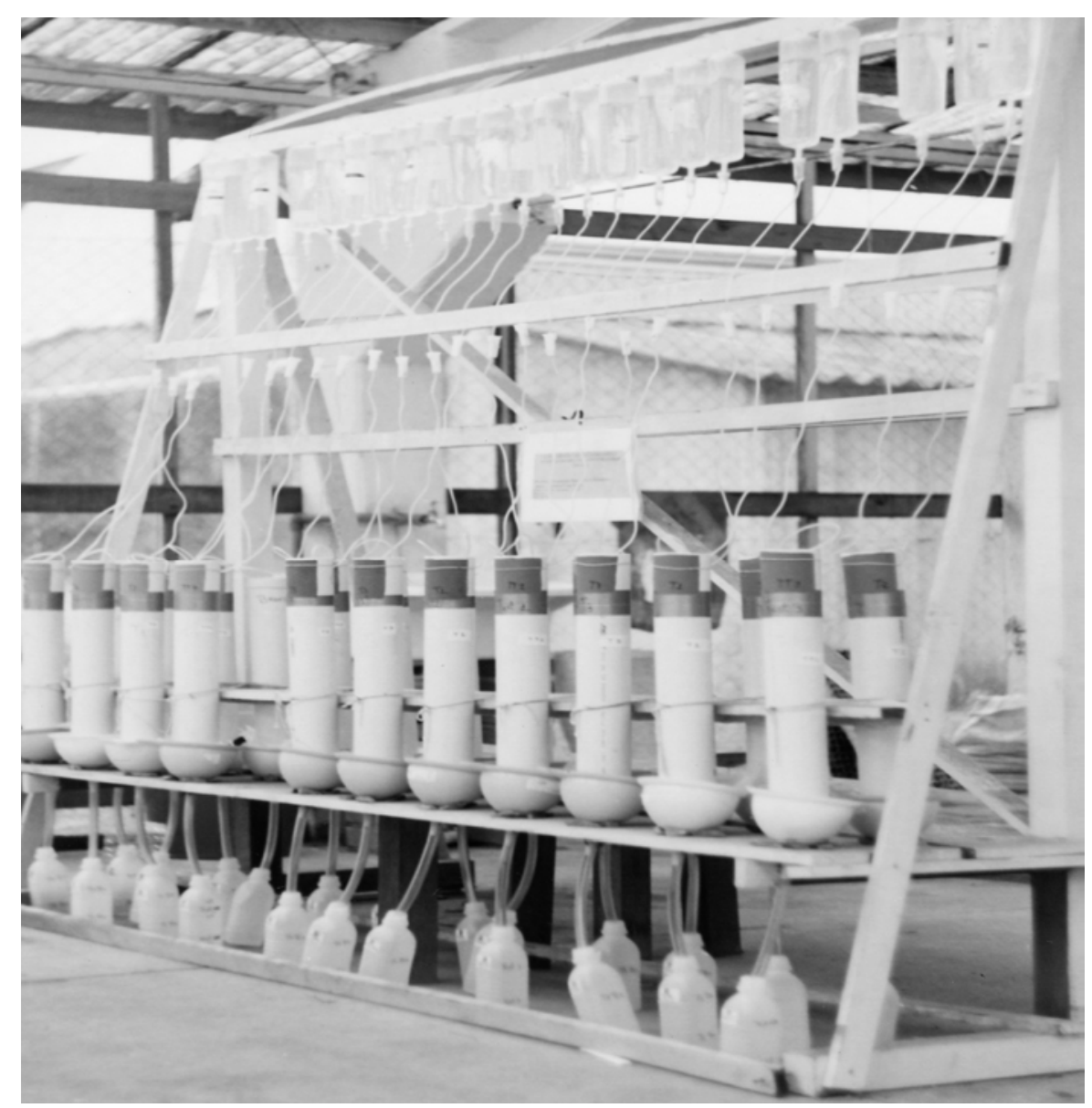

Figure 1 - Leaching columns experiment aspects

The comparison between the average levels on leached solutions elements in the experimental set with alkalinized sewage sludge and doses of potassium were done by a simple linear regression analysis, and in the case of the adjustment lack, basic methodology of statistics. The effect of ASS presence was evaluated through the averages of the elements leached between the experimental sets, for the same dose of potassium, with alkalinized sewage sludge and without ASS using the statistics basic methodology reliable interval, adjusted in 90\% (Spiegel, 1993).

\section{RESULTS AND DISCUSSION}

\section{pH in the leached solutions}

When increased the dose of $\mathrm{K}_{2} \mathrm{O}$ in the soil, in all leached solutions, there was an increase in the $\mathrm{pH}$ values, $\left(\boldsymbol{1}^{a} y=4.086+0.0014 * X\right.$ and $r^{2}=0.54$; $2^{a} y=4.1733+0.0015^{*} X$ and $r^{2}=0.69$; $3^{a} y=4.0133+0.0015 * X$ and $r^{2}=0.50$; $4^{a} y=4.1533+0.0014 * X$ and $r^{2}=0.59$, being $y=$ $p H$ and $x=$ potassium dose). As it can be observed in Table 2, $\mathrm{pH}$ varied from 3.80 to 4.60 . This 0.8 difference between the greater and the smaller dose of $\mathrm{K}_{2} \mathrm{O}$ is not very representative, because the $\mathrm{pH}$ is kept very below of the minimum value allowed by the CONAMA, Resolution (1986), which is 6.0 for $\mathrm{pH}$ in water. 
Being thus, working with final deposition of organic residues, according to Machado (1985), the low pH of soil's solution can solublise heavy metals from the soil solution and to compromise the quality of the water sources, being able to reach levels of toxicity to the plants and the animals.

In the comparison among the leached solutions of $\mathrm{pH}$ 's average, for the two sets of experimental units, for the same dose of potassium, it was evidenced differences in leached solutions $\mathrm{pH}$ 's average at the $3^{\mathrm{a}}$ and $4^{\mathrm{a}}$ leachings. The $\mathrm{pH}$ 's average at the leached solutions was lower in soil treated with sewage sludge (Table 3). Probably, the differences founded were due to the presence of organic acid released by microorganisms during the organic matter decomposition added by the sewage sludge, being able also to be associated to the nitrification reactions of the ammoniac $\mathrm{N}$.

Table 2 - Soil's $\mathrm{pH}$ variation in water in the first level $(0-20 \mathrm{~cm})$ and second level $(20-40 \mathrm{~cm})$ with and without alkalinized sewage sludge at the end of experiment

\begin{tabular}{lcc}
\hline Treatment & pH 0-20 cm & pH 20-40 cm \\
\hline without/ASS 100* & 5,96 & 4,89 \\
with/ASS 0 & 6,13 & 4,83 \\
with/ASS 50 & 6,30 & 4,80 \\
with/ASS 100 & 6,43 & 4,83 \\
with/ASS 15 & 6,46 & 4,90 \\
with/ASS 200 & 6,43 & 4,86 \\
\hline
\end{tabular}

Without ASS - Soil without alkalinized sewage sludge.

With ASS - Soil with alkalinized sewage sludge.

*Potassium doses per cent $\left(60 \mathrm{~kg} \mathrm{ha}^{-1} \mathrm{~K}_{2} \mathrm{O}\right)$

It was verified, that in the leached solutions, the $\mathrm{pH}$ 's average (4.5) was inferior to the soil's $\mathrm{pH}$ at both layers. Probably, the permanence of low $\mathrm{pH}$ in leached solutions, even when this solution passed through the soil that had received lime in 2001 and sewage sludge application on the superficial layer, can be explained by the passage of the water through the subsurface layer, 20-40 $\mathrm{cm}$, which possess a $\mathrm{pH}$ variation in water between 4.8 to 4.9 , causing part of this acidification.

Another factor that could have contributed to the increase of the hydrogen concentration in the leached solution, related to the soil, is the increase of the ionic force in the soil solution, where the hydrogen ions are dislocated from the negative sites on the colloids surface by the cations added, as realized by Takachi and Pavan (1995). Such increase of ionic force in the experimental set treated with sewage sludge could be considered due to the added residue composition (vide material and methods).

\section{Cations Leaching}

\section{Potassium}

From the statistical analysis results, it was observed a tendency to a potassium concentration increase in the leached solution for the four leaching, following the increases of the $\mathrm{K}_{2} \mathrm{O}$ doses applied to the soil. $\left(1^{a} y=7.6753+0.0562 * X\right.$ and $r 2=0.91 ; \quad 2^{a} y=2.1987+0.0640 * X$ and $r^{2}=$ $0.73 ; 3^{a} y=2.38+0.0541 * X$ and $r 2=0.87 ; 4^{a} y=$ $0.8524+0.0264 * X+0.0005 * X^{2}$ and $r^{2}=0.95$, being $y=$ potassium leached and $x=$ potassium dose).

For the same dose of $\mathrm{K}_{2} \mathrm{O}(100 \%)$, it was detected a significant difference only in the first leaching, between the two experimental sets (Table 3), with a bigger average of potassium leached for soil without sewage sludge. Similar answer were get by Simonete et al. (2003) and Oliveira et al. (2002), that shows positive results of potassium retention with the addition of sewage sludge. Being this potassium retention attributed mainly to the increase of the Cation Exchange Capacity (CEC) provoked by the addition of sewage sludge.

\section{Calcium and Magnesium}

In the same way that in the Bertoncini and Mattiazzo (1999) studies, in this research were identified the presence of cations in the leached solution. According to these authors, probably, the specific adsorption of divalent ions on the surface of the soil oxides, of this experiment, hasn't been enough to hold back all the cations added by the lime and/or by the sewage sludge, justifying the leaching of $\mathrm{Ca}^{2+}$ and $\mathrm{Mg}^{2+}$ observed here. 
Table 3 - pH averages and average concentration of cations in the leached solution through the soil with sewage sludge (with ASS) and without sewage sludge (without ASS), at the dose of $100 \% \mathrm{~K}_{2} \mathrm{O}$

\begin{tabular}{|c|c|c|c|c|c|c|c|c|}
\hline \multirow{2}{*}{$\begin{array}{c}\text { Experimental Set/ } \\
\text { Parameters }\end{array}$} & \multicolumn{2}{|c|}{$1^{\text {a }}$ leaching } & \multicolumn{2}{|c|}{$2^{\mathrm{a}}$ leaching } & \multicolumn{2}{|c|}{$3^{a}$ leaching } & \multicolumn{2}{|c|}{$4^{\mathrm{a}}$ leaching } \\
\hline & $\begin{array}{c}\text { Withou } \\
\text { t ASS }\end{array}$ & $\begin{array}{l}\text { With } \\
\text { ASS }\end{array}$ & $\begin{array}{c}\text { Withou } \\
\text { t ASS }\end{array}$ & $\begin{array}{l}\text { With } \\
\text { ASS }\end{array}$ & $\begin{array}{c}\text { Withou } \\
\text { t ASS }\end{array}$ & $\begin{array}{l}\text { With } \\
\text { ASS }\end{array}$ & $\begin{array}{c}\text { Withou } \\
\text { t ASS }\end{array}$ & $\begin{array}{l}\text { With } \\
\text { ASS }\end{array}$ \\
\hline $\mathrm{pH}$ & 4,35 & 4,23 & 4,29 & 4,32 & 4,34 & 4,17 & 4,55 & 4,29 \\
\hline Significance & \multicolumn{2}{|c|}{ ns } & \multicolumn{2}{|c|}{ ns } & \multicolumn{2}{|c|}{$*$} & \multicolumn{2}{|c|}{$*$} \\
\hline Potassium & 15,4 & 13,3 & 8,4 & 8,6 & 7,04 & 7,8 & 8,06 & 8,06 \\
\hline Significance & \multicolumn{2}{|c|}{$*$} & \multicolumn{2}{|c|}{ ns } & \multicolumn{2}{|c|}{ ns } & \multicolumn{2}{|c|}{ ns } \\
\hline Calcium & 53,21 & 76,2 & 48,46 & 45,1 & 13,96 & 16,3 & 14,5 & 18,8 \\
\hline Significance & \multicolumn{2}{|c|}{$*$} & \multicolumn{2}{|c|}{ ns } & \multicolumn{2}{|c|}{$\mathrm{ns}$} & \multicolumn{2}{|c|}{ ns } \\
\hline Magnesium & 33,2 & 45,3 & 29,6 & 32,0 & 6,9 & 10,4 & 9,0 & 14,9 \\
\hline Significance & \multicolumn{2}{|c|}{$*$} & \multicolumn{2}{|c|}{ ns } & \multicolumn{2}{|c|}{$*$} & \multicolumn{2}{|c|}{$*$} \\
\hline Aluminium & 2,06 & 3,10 & 0,79 & 0,89 & 0 & 0,36 & 0 & 0,14 \\
\hline Significance & \multicolumn{2}{|c|}{$*$} & \multicolumn{2}{|c|}{$\mathrm{ns}$} & \multicolumn{2}{|c|}{$*$} & \multicolumn{2}{|c|}{$*$} \\
\hline
\end{tabular}

ns - Not significant for the confidence interval of $90 \%$

* - Significant for the confidence interval of $90 \%$.

Without ASS - Soil without alkalinized sewage sludge.

With ASS - Soil with alkalinized sewage sludge.

Evaluating the treatments of the experimental set with sewage sludge, among the doses of $\mathrm{K}_{2} \mathrm{O}$, the leached calcium showed significant difference for the first leaching $(y=69.13+0.201 * X$ $0.0013 * X^{2}$ and $r^{2}=0.50$, being $y=$ leached calcium and $x=$ potassium doses), and not significant for the others. In the case of magnesium, there wasn't interference between the leached magnesium and the potassium doses added to the soil, for the four leachings.

When it was compared the couple of experimental sets (with and without sewage sludge), for the dosage of $100 \%$ potassium, was verified a bigger concentration average of leached calcium for the soil with sewage sludge, for the first leaching. The difference in $\mathrm{Ca}^{2+}$ concentration in the leached solution can be justified by the calcium added by the sewage sludge, which, at the soil moistening moment was dislocated in a bigger amount to the solution, and intensively leached in the first simulation of rain, with posterior stabilization.

With relation to the $\mathrm{Mg}^{2+}$, the experimental sets with and without sewage sludge, had presented significant differences in the first, third and fourth leachings. For the experimental set with sewage sludge, as detected by Bertoncini and Mattiazzo (1999), the average of leached magnesium had been bigger than the one of the experimental set without sewage sludge (Table 3 ).

As the sewage sludge is a residue that contains an organic fraction that is easily decomposed, the release of its ions can happen quickly, as well as the release of magnesium from the lime used for the disinfection of the sewage sludge.

\section{Aluminum}

The element $\mathrm{Al}^{3+}$ suffered interference from the doses of potassium added to the soil, answering negatively in all leachins $\left(1^{a} Y=4.247-0.0117 * X\right.$ and $r^{2}=0.33 ; 2^{a} Y=1.313-0.0042 * X$ and $r^{2}=$ $0.72 ; 3^{a} Y=0.74-0.0038^{*} X$ and $r^{2}=0.50 ; 4^{a} Y=$ $-0.516+0.122 * X$ and $r^{2}=0.46$, being $y=$ leached aluminum and $x=$ potassium doses). This negative answer is possibly linked to the displacement of divalent cations, providing bigger adsorption of trivalent ion. In the case of ions with different valences, generally those with bigger charge are more adsorbed by the soil colloids (Meurer et al., 2000).

When comparing the soil with and without sewage sludge, for the same potassium dose, there were significant differences in the aluminum concentrations of the leached solutions, for the first, third and fourth leachings, as shows (Table 3). In their experiments, Simonete et al. (2003) working with $\mathrm{Al}^{3+}$ labile of the soil, had found increment of values due to the acidity increase. Probably the greater concentration of $\mathrm{Al}^{3+}$ in the leached solution for the treatments with sewage sludge is due to the swage sludge composition and the low $\mathrm{pH}$ of the leached solution. 
The average of leached aluminum in the experimental sets with and without sewage sludge, presented in Table 3, show that themselves are superior to the maximum value allowed by the resolution CONAMA $20 / 86\left(0,1 \mathrm{mg} \mathrm{L}^{-1}\right)$. Studies carried through and reported by Freitas et al. (2001) show that the consumption of water contend aluminum above of the national law can provoke a possible increase in the numbers of Alzheimer cases.

\section{Anion Leaching}

\section{Phosphate}

With relation to the $\mathrm{PO}_{4}{ }^{3-}$, it wasn't detected the presence of this anion in any one of leachings, for both of experimental sets, despite being present in the sewage sludge added to the soil and in the phosphate fertilization received during the first phase, by the soil without sewage sludge. Probably, this situation is due to the retention of phosphate by the soil, or by the detection level of the analysis methodology.

\section{Chloride}

The experimental set with sewage sludge showed significant differences among the potassium doses added to the soil and the chloride leaching $\left(1^{a} Y=\right.$ $21.0127-0.689 * X$ and $r^{2}=0.77 ; 2^{a} Y=-0.516+$ $0.1224 * X$ and $r^{2}=0.46 ; 3^{a} Y=1.742+0.0197 * X$ and $r^{2}=0.44 ; 4^{a}=Y-0.77+0.06268 * X$ and $r^{2}=$ 0.78 , being $y=$ leached chloride and $x=$ potassium doses), in all four leachings. The tendency of increase in the chloride concentration in the leached solution is due, mainly, to the increase in the $\mathrm{KCl}$ doses, used as potassium source in this experiment.

Analyzing the concentrations of chlorine leached for both experimental sets, with and without sewage sludge, had been observed significant differences for second and for the third leachings (Table 4). These differences are, possibly, due to chloride activity presented in the sewage sludge, or tramped on it.

Even had been below of the allowed CONAMA20/86 resolution (250 $\left.\mathrm{mg} \mathrm{L}^{-1}\right)$, the averages of leached chlorine, (Table 4), some treatments presented high values, what can generate preoccupation with the accumulating effect on underground waters.

High values of chlorine found in waters can have a positive effect against bacteria and virus, however, it can cause some problems in the "organoleptics" properties Brazil (1990) and public health as Freitas et al. (2001); Calderaro and Heller (2001).

\section{Sulphate}

For the anion $\mathrm{SO}_{4}^{2-}$, potassium dose effect added to the soil did not showed significant differences on its concentration in the leached solution in anyone of the leachings.

Between the two experimental sets, the soil with and without sewage sludge, for the majority of leachings, there weren't significant effects caused by the sewage sludge, as showed on Table 4. Works carried through by Silva et al. (2001) and Simonete et al. (2003) show that the sewage sludge promotes a $\mathrm{SO}_{4}{ }^{2-}$ increase, due to the anion liberation by the organic matter mineralization, followed by the losses of the leaching process. However, for this research, the leached $\mathrm{SO}_{4}{ }^{2-}$ average (Table 4), indicate adsorption to the organic matter proceeding from the sewage sludge, with importance just for the last leaching. The leached $\mathrm{SO}_{4}{ }^{2-}$ average values are very below of the maximum values allowed $\left(250 \mathrm{mg} \mathrm{L}^{-1}\right)$, by the CONAMA, Resolution (1986).

\section{Nitrate}

Observing nitrate concentration at the leached solutions in the soil with sewage sludge and crescents doses of $\mathrm{K}_{2} \mathrm{O}$, was founded significant negative results for the first leaching, $\left(I^{a} y=\right.$ $49.5760-0.0831 * X$ and $r^{2}=0.79$, being $y=$ nitrate and $x=$ potassium doses), and not significant for the others leachings.

The correlation between nitrate and potassium in the leached solution have showed to be very negative for the first leaching $(r=-0.8165)$, however there weren't correlation for the others. Therefore, at the conditions of this experiment, the nitrate leaching weren't linked to the increase in the potassium doses in the soil solution, making possible the recommendation of potassium fertilization as complement of the soils sewage sludge treatment of the. 
Table 4 - Anions average concentration in the leached solution trough a soil with sewage sludge and other without sewage sludge, in the dose of $100 \%$ of $\mathrm{K}_{2} \mathrm{O}$

\begin{tabular}{|c|c|c|c|c|c|c|c|c|}
\hline \multirow[b]{2}{*}{$\begin{array}{c}\text { Experimental set/ } \\
\text { Parameters }\end{array}$} & \multicolumn{2}{|c|}{$1^{\text {a }}$ Leaching } & \multicolumn{2}{|c|}{$2^{\mathrm{a}}$ Leaching } & \multicolumn{2}{|c|}{$\mathbf{3}^{\mathrm{a}}$ Leaching } & \multicolumn{2}{|c|}{$4^{\mathrm{a}}$ Leaching } \\
\hline & $\begin{array}{l}\text { Withou } \\
\text { t ASS }\end{array}$ & $\begin{array}{l}\text { With } \\
\text { ASS }\end{array}$ & $\begin{array}{c}\text { Withou } \\
\text { t ASS }\end{array}$ & $\begin{array}{l}\text { With } \\
\text { ASS }\end{array}$ & $\begin{array}{l}\text { Withou } \\
\text { t ASS }\end{array}$ & $\begin{array}{l}\text { With } \\
\text { ASS }\end{array}$ & $\begin{array}{l}\text { Withou } \\
\text { t ASS }\end{array}$ & $\begin{array}{l}\text { With } \\
\text { ASS }\end{array}$ \\
\hline Nitrate & 35.8 & 41.3 & 35.5 & 33.4 & 10.3 & 13.1 & 10.1 & 14.8 \\
\hline Significance & \multicolumn{2}{|c|}{$*$} & \multicolumn{2}{|c|}{ ns } & \multicolumn{2}{|c|}{$*$} & \multicolumn{2}{|c|}{$*$} \\
\hline Sulphate & 8.60 & 7.79 & 4.04 & 4.19 & 5.62 & 5.08 & 3.60 & 0.717 \\
\hline Significance & \multicolumn{2}{|c|}{$\mathrm{ns}$} & \multicolumn{2}{|c|}{$\mathrm{ns}$} & \multicolumn{2}{|c|}{ ns } & \multicolumn{2}{|c|}{$*$} \\
\hline Chloride & 102.75 & 89.91 & 5.64 & 11.72 & 1.23 & 3.71 & 2.32 & 5.50 \\
\hline Significance & \multicolumn{2}{|c|}{$\mathrm{ns}$} & \multicolumn{2}{|c|}{$*$} & \multicolumn{2}{|c|}{ * } & \multicolumn{2}{|c|}{$\mathrm{ns}$} \\
\hline
\end{tabular}

ns - Not significant for the confidence interval of $90 \%$.

* - Significant for the confidence interval of $90 \%$.

Without ASS - Soil without alkalinized sewage sludge.

With ASS - Soil with alkalinized sewage sludge.

When confronting the experimental sets with and without sewage sludge, it was evident that the leached nitrate averages were superior for the soil with sewage sludge in all leachings (Table 4), showing statistic differences significant for the first third and fourth leachings This results agree with the results of the researches realized by Anjos (1999); Oliveira et al. (2001); Vieira and Cardoso (2003), that showed looses of $\mathrm{NO}_{3}{ }^{-}$in soils treated with sewage sludge, for the superficial layers. The doses of sewage sludge used in that researches goes from 12 to $388 \mathrm{Mg} \mathrm{ha}{ }^{-1}$ (dry base) respectively, with crops on the soil surface. However, Andrade and Matiazzo (2000), did not found looses of nitrate in a Eucalyptus grandis forest soil treated with sewage sludge, even with doses that varied from 10 to $40 \mathrm{Mg} \mathrm{ha}^{-1}$ (dry base).

With relation to the experimental sets and without sewage sludge, the nitrate showed for the four leachings, average values superior to $10 \mathrm{mg} \mathrm{L}^{-1}$ (reference value, Brasil 1990), for all the treatments, justified for the fact that there wasn't vegetal covering the ground during the projects second phase. The maximum and minimum average amount of nitrate lost for layers below of $40 \mathrm{~cm}$ of depth, had been 12.52 and $48.14 \mathrm{mg} \mathrm{L}^{-1}$, that is equivalent, respectively to 13.19 and 50.73 $\mathrm{kg}$ of $\mathrm{N} \mathrm{ha}^{-1}$, to this period of four months with $465 \mathrm{~mm}$ of precipitation. This indicates a potential of supplement for the nutritional necessities of diverse plants, what in the case of the cultivated soil would prevent or reduce losses in depth and environment risks. Some authors, as Alaburda and Nishihara (1998), consider that concentrations superior to $3 \mathrm{mg} \mathrm{L}^{-1}$ of $\mathrm{NO}_{3}^{-}$in water samples are indicative of contamination by anthropogenic activities.

It is valid to stand out that, in work carried through by Freita et al. (2001), the nitrate represents a risk for the public health, since several works associate the consumption of water contend high concentrations of nitrate to the appearance of the metemoglobinemia, especially in children, and the potential formation of carcinogenic nitrosamines and nitrosamides.

The explanation to the greater concentration of nitrate in the first leached solution, for the treatments with 0 and $50 \%$ of recommended $\mathrm{K}_{2} \mathrm{O}$, probably was related to the maize dry mass, produced in the previous phase of the research, carried through by Veiga (2002), which presented smaller development in the treatments that had received inferior dosages of recommended potassium for this crop. Thus, the previously cultivated crop extracted less nitrogen, possibly resulting in more raised residual values of nitrate in the soil (Bull et al., 1993), with liberation during the beginning of the leaching process in the second phase of the research.

It is recommended, still, that when utilizing alkalized sewage sludge, the soil surface be kept with vegetal covering, so that the root system uses mineralized nitrate, aiming nitrate leachings below $10 \mathrm{mg} \mathrm{L}^{-1}$. Though, even in cultivated soils, when planning the sewage sludge addition based on the mineralized fraction of $\mathrm{N}$, and on the petition of this element by the crop, must be taken care of soil $\mathrm{NO}_{3}{ }^{-}$losses, that can result harmful to the environment, mainly if during the initial development of the crop there are water excess, as due to the irrigation, as to high rainfall. 


\section{CONCLUSIONS}

There was an increase in the $\mathrm{K}^{+}$and $\mathrm{Cl}^{-}$ concentration in the leached solution, as it was increased the potassium dose, in the four leachings, for the experimental set with sewage sludge, without increase in the leached nitrate.

The $\mathrm{Al}^{3+}$ concentration in the leached solution was diminished with the increase of the $\mathrm{KCl}$ dose. However, they had remained superior to $0.1 \mathrm{mg} \mathrm{L}^{-}$ 1 , CONAMA, Resolution (1986).

The sewage sludge addition had increased the $\mathrm{NO}_{3}^{-}, \mathrm{Cl}^{-}, \mathrm{Ca}^{2+}$ and $\mathrm{Mg}^{2+}$ concentration most of leaching solutions.

The minimum average values of nitrate concentration in the solutions leached through the soil profile without crop coverage, for all treatments, and for the four leachings, had been superior to $10 \mathrm{mg} \mathrm{L}^{-1}$, CONAMA, Resolution (1986).

\section{RESUMO}

O objetivo deste trabalho foi avaliar a interferência do potássio, utilizado como adubo suplementar, na lixiviação química de íons, em um solo que fora tratado com lodo de esgoto alcalinizado (LEA) e cultivado com milho em 2001. O estudo foi desenvolvido na casa de vegetação do Setor de Ciências Agrárias em Curitiba, em 2002/2003, instalado em colunas de PVC de $60 \mathrm{~cm}$ de altura e $7,5 \mathrm{~cm}$ de diâmetro. Mediante a análise dos resultados do experimento com LEA, verificou-se na solução lixiviada aumento da concentração de potássio e cloreto, bem como a redução da concentração de $\mathrm{Al}^{3+}$, à medida que se aumentou a adubação potássica no solo, nas quatro lixiviações. A presença de lodo de esgoto alcalinizado aumentou a concentração de $\mathrm{NO}_{3}^{-}, \mathrm{Cl}^{-}, \mathrm{Ca}^{2+}, \mathrm{Mg}^{2+}$ e $\mathrm{Al}^{3+}$ nas soluções na maioria das lixiviações. Verificou-se valores de $\mathrm{Al}^{+3}$ superiores a $0,1 \mathrm{mg} \mathrm{L}^{-}$ ${ }^{1}$ nas quatro lixiviações, para o solo com LEA. Para o nitrato, todas as soluções apresentaram valores superiores ao valor máximo permitido pela legislação vigente $\left(10 \mathrm{mg} \mathrm{L}^{-1}\right)$.

\section{REFERENCES}

Alaburda, J. and Nishihara, L. (1998), Presença de compostos de nitrogênio em águas de poços. Rev. de Saúde Pública., 32, 160-165.

Andrade, C. A. and Mattiazzo, M. E. (2000), Nitratos e metais pesados no solo e nas árvores após aplicação de biossólido (lodo de esgoto) em plantações florestais de Eucalyptus grandis. Scientia Forestalis, 58, 59-72.

Andreoli, C. V. (1999), Uso e manejo do lodo de esgoto na agricultura e sua influência em parâmetros ambientais. 278 ff. Tese (Doutorado) - Universidade Federal do Paraná. Curitiba.

Anjos, A. R. M. (1999), Lixiviação de espécies químicas em latossolos sucessivamente tratados com biossólido e disponibilidade de metais pesados para plantas de milho. $191 \mathrm{ff}$. Tese (Doutorado) - Escola superior de Agricultura Luiz de Queiroz, Universidade de São Paulo. Piracicaba.

Berton, R. S. (1989), Especiação iônica da solução do solo: metodologia e aplicações. In: Dechen, A. R.; Carmello, Q. A. C. and Floss, E. L. (Coords.). Simpósio Avançado de Solos e Nutrição de Plantas, 2., 1989, Piracicaba. Anais... Piracicaba: Fundação Cargil.

Bertoncini, E. I. and Mattiazzo, M. E. (1999), Lixiviação de metais pesados em solos tratados com lodo de esgoto. Rev. Bras. Cien. Solo, 23, 737-744.

Brasil. Ministério da Saúde. (1990), Divisão Nacional de Vigilância Sanitária de Alimentos. Portaria n. 36 SVS/MS, de 19 de janeiro de 1990. Compêndio de legislação de alimentos. São Paulo: ABIA. pp. 711-777.

Bull, J. M.; Boaretto, A. E.; Mello, F. A. F. and Soares, E. (1993), Influência da relação $\mathrm{k} / \mathrm{Ca}=\mathrm{Mg}$ do solo na produção de massa seca e na absorção de potássio por gramínea e leguminosa forrageiras: II. Absorção de potássio em função da relação $\mathrm{k} / \mathrm{Ca}=\mathrm{Mg}$ no complexo de troca do solo. Cien. Rio de Janeiro, 21, 67-75.

Calderaro, R. W. and Heller, L. (2001), Surto de reações hemolíticas associado a residuais de cloro e cloraminas na água de hemodiálise. Rev. de Saúde Pública, 35, 481- 486.

Comissão de Fertilidade do Solo - RS/SC (1994), Recomendações de adubação e calagem para os estados do Rio Grande do Sul e de Santa Catarina. 3. ed. Passo Fundo: SBCS-Núcleo Regional Sul. pp. 223.

Eaton, A. D.; Clesceri, L. S. and Grennberg, A. S. (1995), Standard methods for the axamination of water and wastewater. 19. ed. Washington: APHA, AWWA, WEF. pp.1082.

Fernandes, F. and Andreoli, C. V. (Coord.). (1997), Manual técnico para utilização agrícola do lodo de esgoto no Paraná. Curitiba: SANEPAR. pp.96. 
Freitas, B. M.; Brilhante, O. M. and Almeida, L. M. (2001), Importância da análise de água para a saúde pública em duas regiões do Estado do Rio de Janeiro: enfoque para coliformes fecais, nitrato e alumínio. Cad. de Saúde Pública, 17, 651-660.

Machado, J. L. F. (1985) Mineração de carvão: contaminação e vulnerabilidade dos mananciais. In: Simpósio Sul Brasileiro de Geologia, 2., Florianópolis. Anais... Florianópolis: UFSC, pp. 539-551.

Meurer, E. J.; Bissani, C. A. and Selbach, P. A. (2000), Poluentes do solo e do ambiente. In: Meurer, E.J. Fundamentos de Química do Solo. Porto Alegre: Gênesis. pp. 174.

Miyazawa, M.; Pavan, M. A. and Block, M. F. M. (1985), Determinação espectrofotométrica de nitrato em extratos de solo sem redução química. Pesq. Agrop. Bras., 20, 129-133.

Murphy, J. and Riley, J. P. (1962), A modified single solution method for the determination of phosphate in natural waters. Analyt. Chim. Acta, 27, 31-36.

Oliveira, C. F.; Mattiazzo, M. E.; Marciano, R. C. and Moraes, S. O. (2001) Lixiviação de nitrato em um latossolo amarelo distrófico tratado com lodo de esgoto e cultivado com cana-de-açúcar. Rev. Bras. de Ciên. do Solo, 58, 171-180.

Oliveira, C. F.; Mattiazzo, M. E.; Marciano, R. C. and Rossetto R. (2002), Efeitos de aplicações sucessivas de lodo de esgoto em um latossolo amarelo distrófico cultivado com cana-de-açúcar: carbono orgânico, condutividade elétrica, $\mathrm{pH}$ e CTC. Rev. Bras. de Ciên. do Solo, 26, 505-519.

Oliveira, F. C.; Marques, M. O.; Bellingieri, P. A.; Perecin, D. (1995), Lodo de esgoto como fonte de macronutrientes para a cultura de sorgo granífero. Scien. Agríc., 52 : (2).

Perkin-Elmer, N. (1973), Analytical methods for atomic absorption spectrophotometry agriculture. Connecticut: Perkin Elmer Norwalck.

Programa de Pesquisa e Saneamento Básico (1999), Uso e manejo do lodo de esgoto na agricultura. Rio de Janeiro: PROSAB. pp. 97.

Resolução Conama n. 20 (1986), Classificação das águas doces, salobras e salinas do Território Nacional. Diário Oficial [da República Federativa] do Brasil. 30/07/1986. Secção 1. Brasília. pp. 1135611361.

Silva, F. C. (1995), Uso agronômico de lodo de esgoto: efeitos em fertilidade do solo e qualidade da cana-deaçúcar. 165 ff. Tese (Doutorado) - Escola Superior de Agricultura Luiz de Queiroz, Universidade de São Paulo. Piracicaba.

Silva, F. C.; Boaretto, A. E.; Berton, R. S.; Zotelli, H. B.; Pexe, C. A. and Bernardes, L. M. (2001), Efeito do lodo de esgoto na fertilidade de um Argissolo Vermelho-amarelo cultivado com cana-de-açúcar. Pesq. Agrop. Bras., 36 : (5), 831-840.
Simonete, M. A.; Kiehl, J. C.; Andrade, C. A. and Teixeira, C. F. A. (2003), Efeito do lodo de esgoto em um Argissolo e no crescimento e nutrição de milho. Pesq. Agrop. Bras., 38, 1187-1195.

Spiegel, M. R. (1993), Estatísitica. 3. ed. São Paulo: Makron Books.

Takachi, C. Y. and Pavan, M. A. (1995), Efeitos da natureza e da força iônica do cátion na acidez da solução do solo. Rev. Bras. de Cien. do Solo, 19, 15-18.

Tedesco, M. J.; Gianello, C.; Bissani, C. A.; Bohenen, H. and Volkweiss, S. L. (1995), Análises de solo, plantas e outros materiais. 2. ed. Porto alegre: UFRGS, Departamento de Solos. (Boletim técnico, 5).

Veiga, A. M. (2002), Lodo de esgoto alcalinizado e níveis de potássio nos parâmetros de crescimento e na absorção de Ca, Mg K, Zn, Mn e Fe, na cultura do milho. Dissertação (Mestrado), Setor de Ciências Agrárias, Universidade Federal do Paraná. Curitiba.

Vieira, R. F. and Cardoso, A. A. (2003), Variação nos teores de nitrogênio mineral em solo suplementado com lodo de esgoto. Pesq. Agrop. Bras., 38, 867-874.

Received: July 05, 2004; Revised: December 02, 2004; Accepted: February 09, 2006. 